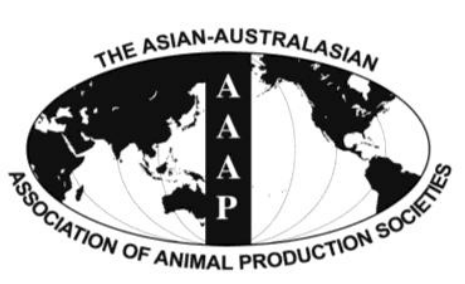

\begin{tabular}{c} 
Open Access \\
$\begin{array}{c}\text { Asian Australas. J. Anim. Sci. } \\
\text { Vol. 27, No. } 8: \text { 1157-1163 August } 2014 \\
\text { http://dx.doi.org/10.5713/ajas.2013.13768 }\end{array}$ \\
\hline $\begin{array}{c}\text { www.ajas.info } \\
\text { pISSN 101 1-2367 elSSN 1976-5517 }\end{array}$
\end{tabular}

\title{
Effects of Gas Composition in the Modified Atmosphere Packaging on the Shelf-life of Longissimus dorsi of Korean Native Black Pigs-Duroc Crossbred during Refrigerated Storage
}

\author{
Muhlisin $^{1,2}$, Panjono ${ }^{2}$, Dong Soo Kim ${ }^{1}$, Yeong Rae Song ${ }^{1}$, Sung-Jin Lee ${ }^{3}$, Jeong Koo Lee ${ }^{4}$, and Sung Ki Lee ${ }^{1, *}$ \\ ${ }^{1}$ Department of Animal Products and Food Science, Kangwon National University, Chuncheon 200-701, Korea
}

\begin{abstract}
This study was conducted to observe the effects of gas composition in modified atmosphere packaging (MAP) on the shelf-life of Longissimus dorsi of Korean Native Black Pigs-Duroc Crossbred (KNP×D) during refrigerated storage. Muscle sample was obtained from the left side of carcass of seven months old of KNP $\times \mathrm{D}$ barrow. The sample was sliced into $1 \mathrm{~cm}$ in thickness, placed on trays (two slices/tray) and filled with different gas composition, i.e. 0:20:80/O $: \mathrm{CO}_{2}: \mathrm{N}_{2}(\mathrm{MAP} 1), 30: 20: 50 / \mathrm{O}_{2}: \mathrm{CO}_{2}: \mathrm{N}_{2}(\mathrm{MAP} 2)$ and 70:20:10/O $\mathrm{O}_{2}: \mathrm{CO}_{2}: \mathrm{N}_{2}$ (MAP3). Other slices of sample were vacuum packed (VP) as a control. All packs were stored at $5 \pm 1{ }^{\circ} \mathrm{C}$. At $12 \mathrm{~d}$ of storage, $\mathrm{pH}$ value of MAP2 and MAP3 were higher $(\mathrm{p}<0.05)$ than that of MAP1 and $\mathrm{pH}$ value of MAP1 was higher $(\mathrm{p}<0.05)$ than that of VP. At $6 \mathrm{~d}$ of storage, redness $\left(\mathrm{a}^{*}\right)$ value of MAP2 and MAP3 were higher $(\mathrm{p}<0.05)$ than that of VP and MAP1 and, at 9 and $12 \mathrm{~d}$ of storage, redness value of MAP3 was higher $(\mathrm{p}<0.05)$ than that of VP, MAP1, and MAP2. At 3, 6, 9, and $12 \mathrm{~d}$ of storage, the 2thiobarbituric acid reactive substances (TBARS) value of MAP3 was higher than that of MAP2 and TBARS value of MAP2 was higher than that of VP and MAP1. At 3, 6, 9, and $12 \mathrm{~d}$ of storage, volatile basic nitrogen values of MAP2 and MAP3 were higher (p<0.05) than those of VP and MAP1. At $3 \mathrm{~d}$ of storage, total aerobic plate counts of MAP2 and MAP3 were higher $(\mathrm{p}<0.05)$ than those of VP and MAP1 and, at $6 \mathrm{~d}$ of storage, total aerobic plate counts of MAP3 was higher $(\mathrm{p}<0.05)$ than that of MAP1 and MAP2. However, there was no significant different total aerobic plate count among MAP1, MAP2, and MAP3 at 9 and $12 \mathrm{~d}$ of storage. There was no significant different total anaerobic plate count among MAP1, MAP2, and MAP3 during storage. It is concluded that the MAP containing 30:20:50/ $\mathrm{O}_{2}: \mathrm{CO}_{2}: \mathrm{N}_{2}$ gas composition (MAP2) might be ideal for better meat quality for $\mathrm{KNP} \times \mathrm{D}$ meat. (Key Words: Modified Atmosphere Packaging (MAP), Korean Native Black Pigs Crossbred with Duroc, Storage Time, Meat Quality)
\end{abstract}

\section{INTRODUCTION}

Korean native black pig (KNP) is typical of native pigs residing in the Korean peninsula which have particularly high intramuscular contents and high redness as compared to other commercial breeds, such as Landrace and Yorkshire (Jin et al., 2001; Kim et al., 2008). However, due to its slow

\footnotetext{
* Corresponding Author: Sung Ki Lee. Tel: +82-33-250-8646, Fax: +82-33-251-7719, E-mail: skilee@kangwon.ac.kr

2 Faculty of Animal Science, Universitas Gadjah Mada, Yogyakarta 55281, Indonesia.

3 Department of Animal Biotechnology, Kangwon National University, Chuncheon 200-701, Korea.

${ }^{4}$ Department of Animal Resources Science, Kangwon National University, Chuncheon 200-701, Korea.

Submitted Nov. 28, 2013; Revised Feb. 16, 2014; Accepted Mar. 3, 2014
}

growth rate and light carcass (Hwang et al., 2004) it has been crossbred with commercial breeds, such as Duroc. Duroc is usually used as a sire breed due to its excellent growth rate (Suzuki et al., 2003) and intramuscular fat deposition and carcass traits (Latorre et al., 2003) and, therefore, KNP $\times$ Duroc crossbred $(\mathrm{KNP} \times \mathrm{D})$ meat is regarded as having a high intramuscular fat and redness value.

Meat is usually offered to the consumers in a refrigerated showcase display. Appearance of meat during display in the showcase is the most important factor in attracting consumers to buy and the shelf-life of meat during display is important to maintain consumer's preference. Therefore, a study of packaging method to preserve the quality of $\mathrm{KNP} \times \mathrm{D}$ meat, particularly its red color, is needed.

Copyright @ 2014 by Asian-Australasian Journal of Animal Sciences This is an open-access article distributed under the terms of the Creative Commons Attribution Non-Commercial License (http://creativecommons.org/licenses/by-nc/3.0/), which permits unrestricted non-commercial use, distribution, and reproduction in any medium, provided the original work is properly cited. 
Modified atmosphere packaging (MAP) is commonly used in the food industry to maintain the quality and extend the shelf-life of meat. McMillin et al. (2008) stated that MAP is the removal and/or replacement of the atmosphere surrounding the product before sealing in vapor-barrier materials. There are three gases which are mainly used in MAP, i.e. oxygen $\left(\mathrm{O}_{2}\right)$, carbon dioxide $\left(\mathrm{CO}_{2}\right)$ and Nitrogen $\left(\mathrm{N}_{2}\right)$. Oxygen is used for its ability to promote the reddish color of fresh meat and maintain it during storage (McMillin, 2008). Studies by meat scientists reported the effect of high oxygen MAP on preserving the bright red color of meat (Jayasingh et al., 2002; Seyfert et al., 2004; Mancini and Hunt, 2005). However, high oxygen MAP has limitations due to its oxidative activity (Grobbel et al., 2008; Zakrys et al., 2008) and caused premature browning during cooking (John et al., 2005). Moreover, oxygen generally stimulates aerobic bacterial growth and inhibits growth sensitive anaerobes (Church, 1994). Carbon dioxide performs antimicrobial effects but absorption of a large amount of carbon dioxide in meat tissue can cause a minor decrease in $\mathrm{pH}$ which might affect other chemical qualities and elevated carbon dioxide levels can cause pore formation in cooked meat (Jakobsen and Bertelsen, 2002). Nitrogen is used as a filler gas as well as to prevent pack collapse caused by high concentration of carbon dioxide (Phillips, 1996).

Oxygen, carbon dioxide and nitrogen are used in different combinations and many studies related to their composition in MAP have been done by meat scientists to extend the shelf-life of meat. However, ambiguous results have been obtained with regard to the longer shelf-life of MAP (Samelis and Georgiadou, 2000; Pexara et al., 2002; Santos et al., 2005). Moreover, there is only a little information about packaging KNP $\times \mathrm{D}$ meat. Therefore, this study was conducted to observe effects of the gas composition in the MAP on the shelf-Life of Longissimus dorsi of $\mathrm{KNP} \times \mathrm{D}$ during refrigerated storage.

\section{MATERIALS AND METHODS}

\section{Sample preparation and experimental design}

Seven months old $\mathrm{KNP} \times \mathrm{D}$ barrows were slaughtered in a commercial slaughtering house followed by overnight chilling. The Longissimus dorsi muscles were obtained from the left side of carcass. The muscles were vacuumed packaged and were transported to laboratory. The muscles were sliced into $1 \mathrm{~cm}$ in thickness and placed on trays $\left(\mathrm{O}_{2}\right.$ transmission rate $=0.1 \mathrm{cc} / \mathrm{cm}^{2}$ at $23^{\circ} \mathrm{C}, 0 \%$ relative humidity (RH); water vapor transmission rate was $7.87 \mathrm{mg}$ / $24 \mathrm{~h}-\mathrm{cm}^{2}$ at $38^{\circ} \mathrm{C}, 100 \% \mathrm{RH}$, Cryovac Sealed Air Corp., Duncan, South Carolina, USA) for packaging. Every tray contained two slices of meat. The trays were filled with different gas compositions, i.e. 0:20:80/ $\mathrm{O}_{2}: \mathrm{CO}_{2}: \mathrm{N}_{2}$ (MAP1),

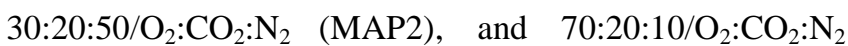
(MAP3). The gas filling was performed using MAP machine (Hypervac, Hwaseong, Korea) equipped with the gas mixture (MAP Mix 9001 ME, PBI Dansensor, Ringsted, Denmark). Gases were purchased from a local gas supplier (Baeklyung Specialty Gas Co., Chuncheon, Korea). Trays were sealed with $\mathrm{O}_{2}$ barrier film $\left(\mathrm{O}_{2}\right.$ transmission rate $=$ $0.39 \mathrm{mg} / 24 \mathrm{~h}-\mathrm{cm}^{2}$ at $4.4^{\circ} \mathrm{C}, 100 \% \mathrm{RH}$; Lid 1050, Cryovac Sealed Air Corp., USA). Other slices of sample were vacuum packed (VP) as a control. All packs were stored at $5 \pm 1^{\circ} \mathrm{C}$.

\section{Shelf-life analysis}

Shelf-life analysis included $\mathrm{pH}$ value, color changes, lipid oxidation, protein deterioration and microbial growth. The analyses were performed at $0,3,6,9$, and $12 \mathrm{~d}$ of storage. Two packages (two slices/samples each) were used at each time of storage.

Ten $\mathrm{g}$ of sample was homogenized with $100 \mathrm{~mL}$ of distilled water at 10,000 rpm for $60 \mathrm{~s}$ using a homogenizer (PH91, SMT Co. Ltd., Tokyo, Japan). The $\mathrm{pH}$ of meat slurry at room temperature was measured using a $\mathrm{pH}$ meter (SevenEasy $\mathrm{pH}$, Mettler-Toledo $\mathrm{GmbH}$, Greifensee, Switzerland).

Color changes of the surface of samples were monitored by measuring the Commission Internationale de I'Eclairage (CIE) color values using a color difference meter (CR-400, Konica Minolta Sensing Inc., Osaka, Japan) and an illuminant $\mathrm{C}$. The color instrument was calibrated using white plate $(Y=93.6, x=0.3134$, and $y=0.3194)$. Color measurements were directly performed on the surface of samples immediately after the packs were opened.

Lipid oxidation was measured by analysis the 2thiobarbituric acid reactive substances (TBARS) values according to Sinnhuber and Yu (1977). A half $\mathrm{g}$ of sample was mixed with 3 drops of antioxidant solution, $3 \mathrm{~mL}$ of TBA solution, and $17 \mathrm{~mL}$ of $25 \%(\mathrm{w} / \mathrm{v}$ ) Trichloroacetic acid (TCA). The mixture was heated at $100^{\circ} \mathrm{C}$ for $30 \mathrm{~min}$ and centrifuged at $3,500 \mathrm{rpm}$ for $30 \mathrm{~min}$. Absorbance of supernatant was measured at $532 \mathrm{~nm}$ using a spectrophotometer (UVmini-1240, Shimadzu, Kyoto, Japan). The results were calculated as $\mathrm{mg}$ of malonaldehyde (MA) per kg of sample.

Protein deterioration was evaluated by measuring the production of volatile basic nitrogen (VBN) values as described by Kohsaka (1975). Five grams of sample were mixed with $30 \mathrm{~mL}$ of $5 \%(\mathrm{w} / \mathrm{v})$ TCA using a homogenizer (Ultra-Turrax T25 basic, IkaWerke GmbH \& Co., Staufen, Germany) at 13,500 rpm for 2 min. The homogenate was made up with $5 \%(\mathrm{w} / \mathrm{v})$ TCA to $50 \mathrm{~mL}$ of final volume and filtered using the Whatman filter paper No. 1. One $\mathrm{mL}$ of filtrate and $1 \mathrm{~mL}$ of borate buffer were placed in outer and inner of Conway dish, respectively. The Conway dishes 
were incubated at $37^{\circ} \mathrm{C}$ for $100 \mathrm{~min}$. Finally, the inner solution was titrated with $0.01 \mathrm{~N} \mathrm{HCl}$ and the titration volume was recorded.

To determine the microbial growth, $10 \mathrm{~g}$ of sample was aseptically transferred into a stomacher bag. The sample then was mixed with $90 \mathrm{~mL}$ of sterile $0.1 \%$ peptone water using a stomacher (Lab blender 400Seward Laboratory, West Sussex, UK) for $2 \mathrm{~min}$ at room temperature. A serial of decimal dilutions was prepared by adding $1 \mathrm{~mL}$ of sample mixture with $9 \mathrm{~mL}$ of $0.1 \%$ peptone water. One $\mathrm{mL}$ inoculum of appropriate dilution was spread on a plate count agar (PCA; Difco, Sparks, Maryland, USA). Plates were incubated at $35^{\circ} \mathrm{C}$ for $48 \mathrm{~h}$ in atmospheric conditions for determination of total aerobic plate count and in anaerobic conditions for total anaerobic plate count. After incubation, plates with 30 to 300 colonies were counted. Microbiological data were transformed into logarithms of the number of colony forming units (Log CFU/g).

\section{Statistical analysis}

The data were analyzed statistically using analysis of variance. Furthermore, Duncan's new multiple range test was used to observe the significant different between means. Analysis was performed using SPSS, version 19.0 (SPSS, 2010).

\section{RESULTS AND DISCUSSION}

\section{Value of pH}

The $\mathrm{pH}$ values of all groups increased as storage time increased (Figure 1) and there was no significant difference in $\mathrm{pH}$ value among groups from 0 to $9 \mathrm{~d}$ of storage. At $12 \mathrm{~d}$ of storage, $\mathrm{pH}$ value of MAP2 and MAP3 were higher $(\mathrm{p}<0.05)$ than that of MAP1 and $\mathrm{pH}$ value of MAP1 was higher $(\mathrm{p}<0.05)$ than that of VP. This showed that oxygen increased the $\mathrm{pH}$ during storage and nitrogen restrained the increasing of $\mathrm{pH}$. However, the trend of $\mathrm{pH}$ regarding packaging type was not consistent. An inconsistent effect of packaging on $\mathrm{pH}$ of pork also was reported by Jeremiah et al. (1995). Different results were reported by Viana et al. (2005) in that MAP did not show strong effects on $\mathrm{pH}$ of fresh pork loin. According to Borch et al. (1996) and Brewer et al. (2001), pH stabilization in fresh meat is attributed to exhaustion of muscular glucose reserves to denaturation of glycolytic enzymes.

\section{Color changes}

The change of $\mathrm{L}^{*}, \mathrm{a}^{*}$ and $\mathrm{b}^{*}$ values is shown in Table 1 . The effect of gas composition of MAP on $\mathrm{L}^{*}$ value can be seen from $3 \mathrm{~d}$ of storage, in which MAP1 $\left(0 \% \mathrm{O}_{2}\right)$ had a lower $L^{*}$ value $(p<0.05)$ than the other MAPs and VP. The $\mathrm{L}^{*}$ values of samples packed with MAPs tended to increase over storage, while vacuum packed samples were constant. Our results disagree with $\mathrm{Li}$ et al. (2012) who reported higher $\mathrm{L}^{*}$ values of beef MAP than VP. Garcia-Esteban et al. (2003) reported that optimized $\mathrm{L}^{*}$ value increased during storage in vacuum packed samples but was stable in MA packed samples. In general, MAP applications do not affect L* values (Soldatou et al., 2009; Esmer et al., 2011).

There was no significant difference of redness $\left(\mathrm{a}^{*}\right)$ value among groups at 0 and $3 \mathrm{~d}$ of storage. At $6 \mathrm{~d}$ of storage, redness values of MAP2 and MAP3 were higher $(\mathrm{p}<0.05)$ than that of VP and MAP1 and, at 9 and $12 \mathrm{~d}$ of storage, redness value of MAP3 was higher $(\mathrm{p}<0.05)$ than that of VP, MAP1, and MAP2. Kerry et al. (2006) stated that the major function of oxygen is to maintain the myoglobin in its oxymyoglobin state which is cherry cherry-red in color. Oxygen contained in MAP had a

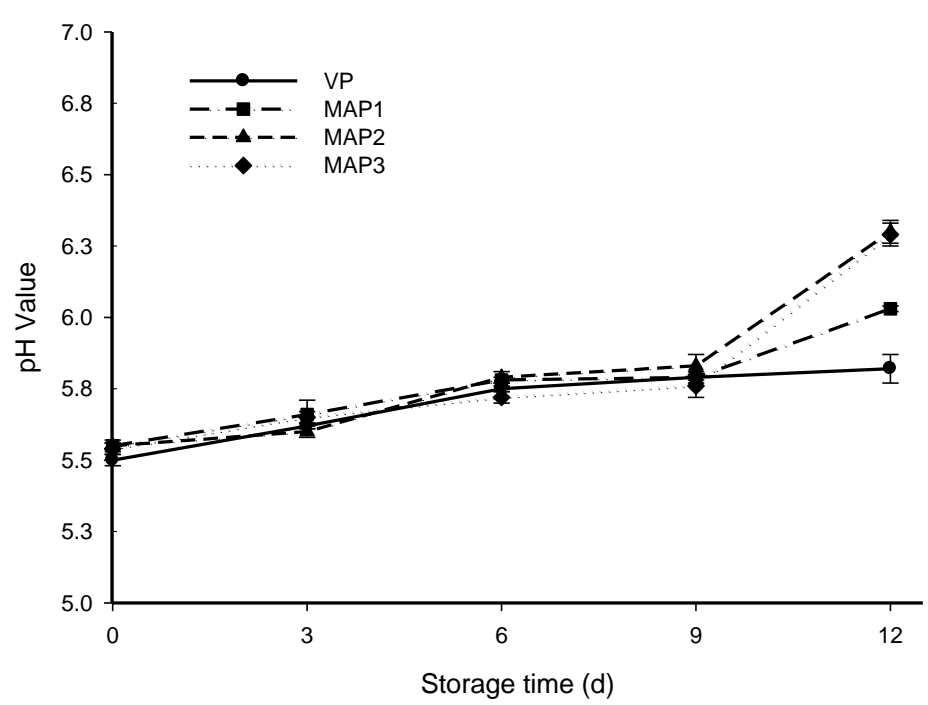

Figure 1. Effect of gas composition in modified atmosphere packaging on pH value of Longissimus dorsi of Korean Native Black Pig crossbred with Duroc during refrigerated storage. VP, vacuum packaging; MAP, modified atmosphere packaging. MAP1 = $0: 20: 80 / \mathrm{O}_{2}: \mathrm{CO}_{2}: \mathrm{N}_{2}, \mathrm{MAP} 2=30: 20: 50 / \mathrm{O}_{2}: \mathrm{CO}_{2}: \mathrm{N}_{2}, \mathrm{MAP} 3=70: 20: 10 / \mathrm{O}_{2}: \mathrm{CO}_{2}: \mathrm{N}_{2}$. 
Table 1. Effect of gas composition in modified atmosphere packaging on $\mathrm{pH}$ and instrumental color of Longissimus dorsi of Korean Native Black Pig crossbred with Duroc during refrigerated storage

\begin{tabular}{lcccccc}
\hline \multirow{2}{*}{ Parameters } & \multirow{2}{*}{ Packaging $^{1}$} & \multicolumn{5}{c}{ Storage time (d) } \\
\cline { 2 - 7 } & & 0 & 3 & 6 & 9 & 12 \\
\hline L* $^{*}$ & VP & $54.76 \pm 3.16^{\mathrm{A}}$ & $53.02 \pm 1.89^{\mathrm{aA}}$ & $54.52 \pm 4.45^{\mathrm{aA}}$ & $54.50 \pm 3.05^{\mathrm{abA}}$ & $54.50 \pm 1.43^{\mathrm{bA}}$ \\
& MAP1 & $53.63 \pm 5.01^{\mathrm{A}}$ & $51.45 \pm 2.01^{\mathrm{bB}}$ & $51.88 \pm 2.28^{\mathrm{bB}}$ & $53.19 \pm 3.02^{\mathrm{bA}}$ & $52.81 \pm 2.55^{\mathrm{cAB}}$ \\
& MAP2 & $53.63 \pm 5.07^{\mathrm{B}}$ & $54.86 \pm 1.99^{\mathrm{aAB}}$ & $55.97 \pm 1.90^{\mathrm{aAB}}$ & $55.52 \pm 1.96^{\mathrm{aAB}}$ & $56.13 \pm 1.83^{\mathrm{aA}}$ \\
& MAP3 & $54.76 \pm 3.16^{\mathrm{AB}}$ & $53.19 \pm 2.04^{\mathrm{aB}}$ & $53.17 \pm 1.27^{\mathrm{abB}}$ & $55.56 \pm 1.27^{\mathrm{aA}}$ & $55.94 \pm 2.49^{\mathrm{abA}}$ \\
$\mathrm{a}^{*}$ & VP & $6.11 \pm 1.03^{\mathrm{B}}$ & $7.54 \pm 1.32^{\mathrm{A}}$ & $7.63 \pm 0.90^{\mathrm{bA}}$ & $5.79 \pm 1.70^{\mathrm{bB}}$ & $6.83 \pm 0.87^{\mathrm{bB}}$ \\
& MAP1 & $6.66 \pm 1.03^{\mathrm{B}}$ & $8.42 \pm 1.15^{\mathrm{A}}$ & $6.45 \pm 1.04^{\mathrm{bB}}$ & $6.21 \pm 1.39^{\mathrm{bB}}$ & $6.87 \pm 1.06^{\mathrm{bB}}$ \\
& MAP2 & $6.62 \pm 1.03^{\mathrm{B}}$ & $9.66 \pm 0.88^{\mathrm{A}}$ & $9.90 \pm 1.65^{\mathrm{aA}}$ & $6.01 \pm 0.74^{\mathrm{bB}}$ & $6.54 \pm 1.49^{\mathrm{bB}}$ \\
$\mathrm{b}^{*}$ & MAP3 & $6.11 \pm 1.39^{\mathrm{C}}$ & $9.73 \pm 1.20^{\mathrm{A}}$ & $9.75 \pm 1.67^{\mathrm{aA}}$ & $8.17 \pm 1.46^{\mathrm{aB}}$ & $7.98 \pm 1.08^{\mathrm{aB}}$ \\
& VP & $2.96 \pm 1.64^{\mathrm{C}}$ & $7.06 \pm 1.09^{\mathrm{bA}}$ & $5.35 \pm 0.94^{\mathrm{bB}}$ & $3.19 \pm 0.69^{\mathrm{bC}}$ & $5.30 \pm 1.07^{\mathrm{bB}}$ \\
& MAP1 & $3.43 \pm 1.07^{\mathrm{A}}$ & $4.52 \pm 1.12^{\mathrm{cA}}$ & $4.55 \pm 1.12^{\mathrm{bA}}$ & $3.62 \pm 0.63^{\mathrm{bA}}$ & $4.12 \pm 0.83^{\mathrm{cA}}$ \\
& MAP2 & $3.43 \pm 1.08^{\mathrm{E}}$ & $8.67 \pm 0.33^{\mathrm{aA}}$ & $7.02 \pm 0.90^{\mathrm{aC}}$ & $7.98 \pm 0.93^{\mathrm{aB}}$ & $6.69 \pm 1.21^{\mathrm{aD}}$ \\
& MAP3 & $2.95 \pm 1.64^{\mathrm{C}}$ & $7.57 \pm 0.80^{\mathrm{bAB}}$ & $7.18 \pm 0.71^{\mathrm{aB}}$ & $7.98 \pm 0.93^{\mathrm{aA}}$ & $6.69 \pm 1.21^{\mathrm{aB}}$ \\
\hline
\end{tabular}

Mean values \pm standard deviation.

VP, vacuum packaging; MAP, modified atmosphere packaging.

${ }^{1}$ MAP1 = 0:20:80/O $2: \mathrm{CO}_{2}: \mathrm{N}_{2}$, MAP2 = 30:20:50/O $: \mathrm{CO}_{2}: \mathrm{N}_{2}, \mathrm{MAP} 3=70: 20: 10 / \mathrm{O}_{2}: \mathrm{CO}_{2}: \mathrm{N}_{2}$.

${ }^{a-d}$ Means in the same column followed by different superscript upper cases are significantly different $(p<0.05)$.

${ }^{\mathrm{A}-\mathrm{E}}$ Means in the same row followed by different superscript upper cases are significantly different $(\mathrm{p}<0.05)$.

significant effect on $a^{*}$ values of samples $(\mathrm{p}<0.05)$, the higher percentage of oxygen showed a greater effect. MAP3 which contained $70 \%$ oxygen increased the initial redness of sample from 6.11 to 9.73 on $3 \mathrm{~d}$ of storage and maintained the highest $\mathrm{a}^{*}$ values among other packaging methods until the end of study. Similar effect of oxygen also was observed from MAP2, in which $30 \%$ oxygen increased the redness on $3 \mathrm{~d}$. These findings agree with Jakobsen and Bartelsen (2000), Jayasingh et al. (2002) and Martinez et al. (2006). Oxygen is required by myoglobin to remain in an oxygenated form, which gives the bright cherry color in meat (Mancini and Hunt, 2005). However, the effect of oxygen was seen only until $6 \mathrm{~d}$. Commencing from $9 \mathrm{~d}, \mathrm{a}^{*}$ values of MAP2 decreased. $\mathrm{a}^{*}$ values of MAP1 and VP were not different $(\mathrm{p}>0.05)$ over storage and remained steady. Martinez et al. (2006) reported that fresh pork sausages stored under vacuum kept a steady acceptable $a^{*}$ value.

Oxygen contained in MAP played role in the increase of $\mathrm{b}^{*}$ values (Table 1). Oxygen concentration of $30 \%$ and $70 \%$ on MAP2 and MAP3 respectively significantly increased the $b^{*}$ values $(p<0.05)$ from 3 to $12 \mathrm{~d}$ of storage. Aida et al. (2013) found an increase of $b^{*}$ values of samples packed under 15:30:50/ $\mathrm{O}_{2}: \mathrm{CO}_{2}: \mathrm{N}_{2}$ which is also agree with the report of Rubio et al. (2008). The $b^{*}$ value of VP was increased on $3 \mathrm{~d}$ then decreased for the rest of storage time. The lowest $b *$ values were found in MAP1 samples.

\section{Lipid oxidation}

TBARS value of all groups increased during storage (Figure 2A). At 3, 6, 9, and $12 \mathrm{~d}$ of storage, TBARS value of MAP3 was higher than that of MAP2 and TBARS value of MAP2 was higher than that of VP and MAP1. This was in accordance with the findings of (Borch et al., 1996; Cayuela et al., 2004; John et al., 2005; Santos et al., 2005; McMillin, 2008). A meat system whereby oxygen is readily available is more oxidatively labile (Smiddy et al., 2002). The occurrence of lipid oxidation can be prevented by anaerobic packaging (Jeremiah, 2001), whereas a greater degree of lipid oxidation is observed in meat stored under high level of oxygen (Jakobsen and Bartelsen, 2000). The TBARS value of samples packed with VP, MAP1, MAP2, and MAP3 increased from initial value of $0.27 \mathrm{mg} \mathrm{MA} / \mathrm{kg}$ sample on $0 \mathrm{~d}$ to $0.42,0.71,1.00$, and $1.27 \mathrm{mg} \mathrm{MA} / \mathrm{kg}$ sample respectively, after $12 \mathrm{~d}$ of storage. Taking into account that TBARS values up to $0.6 \mathrm{mg} \mathrm{MA} / \mathrm{kg}$ of fresh meat are considered as fresh (Tarladgis et al., 1960), samples packed with VP, MAP1, MAP2, and MAP3 were categorized as fresh meat up to $12 \mathrm{~d}, 9 \mathrm{~d}, 3 \mathrm{~d}$ and less than 3 $\mathrm{d}$ of storage respectively. However, TBARS values of sample from all packaging methods were below $2 \mathrm{mg}$ MA $/ \mathrm{kg}$ sample. A TBARS value of 2 was considered the limiting threshold for oxidized meat acceptability (Campo et al., 2006). The TBARS values increased throughout storage in all packaging methods, and the increasing rate of TBARS was higher as the oxygen content in packaging increased. The increasing rate of TBARS throughout storage can be attributed to the increased of oxidation of unsaturated fatty acid (Mendes et al., 2008) which is accelerated by the presence of oxygen (McMillin, 2008).

\section{Protein deterioration}

VBN value of all groups increased during storage (Figure 2B). At 3, 6, 9, and $12 \mathrm{~d}$ of storage, VBN values of 


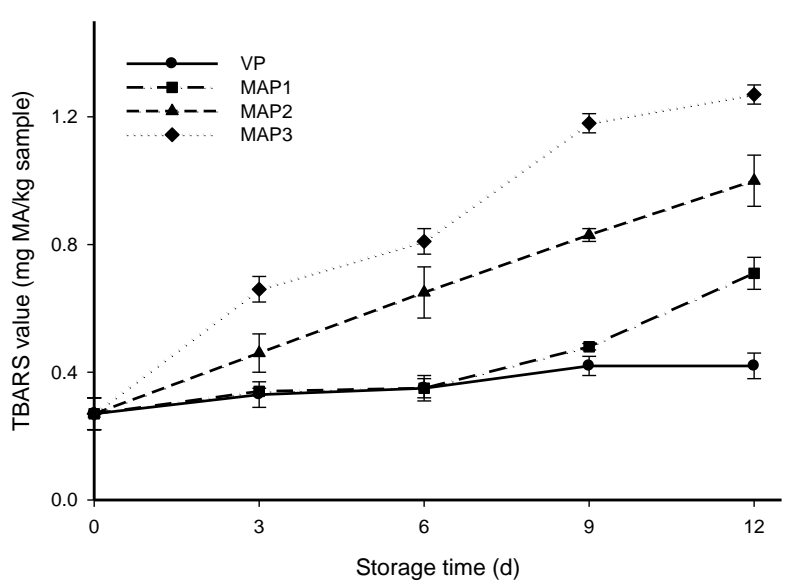

(A)

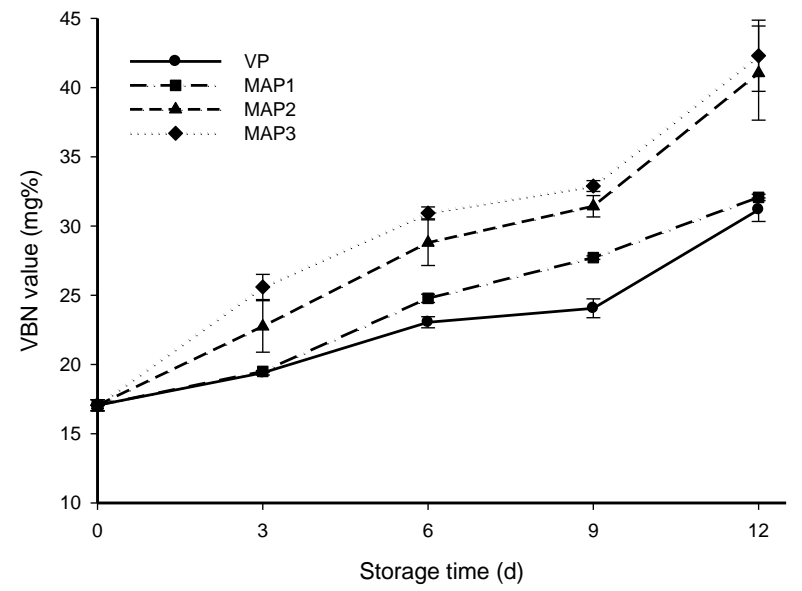

(B)

Figure 2. Effect of gas composition in modified atmosphere packaging on TBARS (A) and VBN (B) of Longissimus dorsi of Korean Native Black Pig crossbred with Duroc during refrigerated storage. VP, vacuum packaging; MAP, modified atmosphere packaging; TBARS, thiobarbituric acid reactive substances; VBN, volatile basic nitrogen. MAP1 $=0: 20: 80 / \mathrm{O}_{2}: \mathrm{CO}_{2}: \mathrm{N}_{2}, \quad \mathrm{MAP} 2=$ $30: 20: 50 / \mathrm{O}_{2}: \mathrm{CO}_{2}: \mathrm{N}_{2}, \mathrm{MAP} 3=70: 20: 10 / \mathrm{O}_{2}: \mathrm{CO}_{2}: \mathrm{N}_{2}$.

MAP2 and MAP3 were higher $(\mathrm{p}<0.05)$ than those of VP and MAP1. Similar findings also were reported by Lund et al. (2007) and Zakrys-Waliwander et al. (2012). Oxygen promoted the protein deterioration of meat represented by the higher VBN values. The higher VBN values of samples packed with higher composition of oxygen might be correlated with the higher counts of bacteria found in those packs (Figure 3A and 3B). Volatile basic nitrogen is a product of bacterial spoilage and endogenous enzyme action (Mendez et al., 2008). Fraser and Sumar (1998) indicated that bacterial catabolism of amino acids results in the accumulation of ammonia and other volatile bases.

\section{Microbial growth}

Total aerobic plate count of all groups increased during

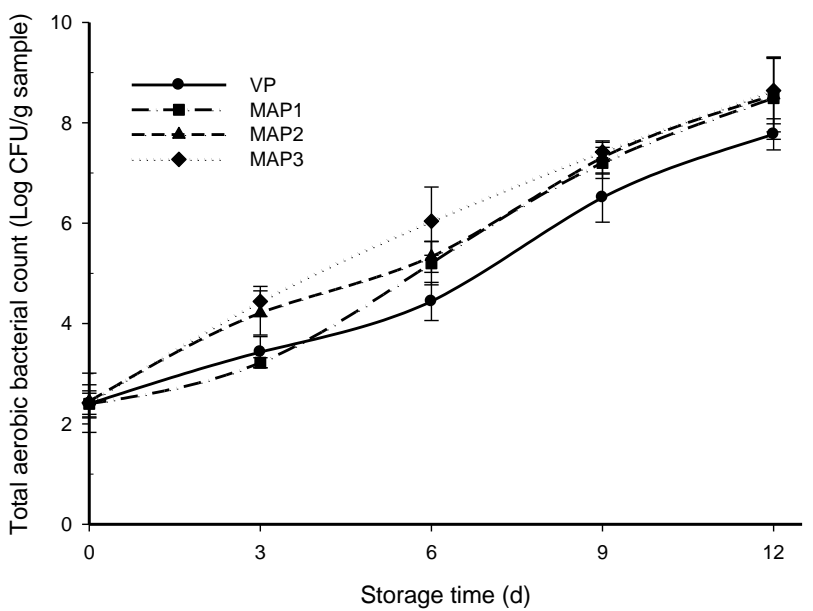

(A) storage (Figure 3A). At $3 \mathrm{~d}$ of storage, total aerobic plate counts of MAP2 and MAP3 were higher $(p<0.05)$ than those of VP and MAP1, and at $6 \mathrm{~d}$ of storage, total aerobic counts of MAP3 was higher $(p<0.05)$ than that of MAP1 and MAP2. However, at 9 and $12 \mathrm{~d}$ of storage, there was no significant different total aerobic plate count among MAP1, MAP2 and MAP3. At 3, 6 and $9 \mathrm{~d}$ of storage, total aerobic plate count of VP was lower $(\mathrm{p}<0.05)$ than that of MAP1, MAP2 and MAP3. Esmer et al. (2011) showed higher viable counts of microbial groups in aerobic packaging (contained $\mathrm{O}_{2}$ ) than those of other packaging methods and this finding agrees with Ercolini et al. (2006). In the lack of oxygen, aerobic microbial grew during refrigerated storage and the presence of oxygen boosted their growth. Church (1994) stated that $\mathrm{O}_{2}$ generally stimulates aerobic bacterial

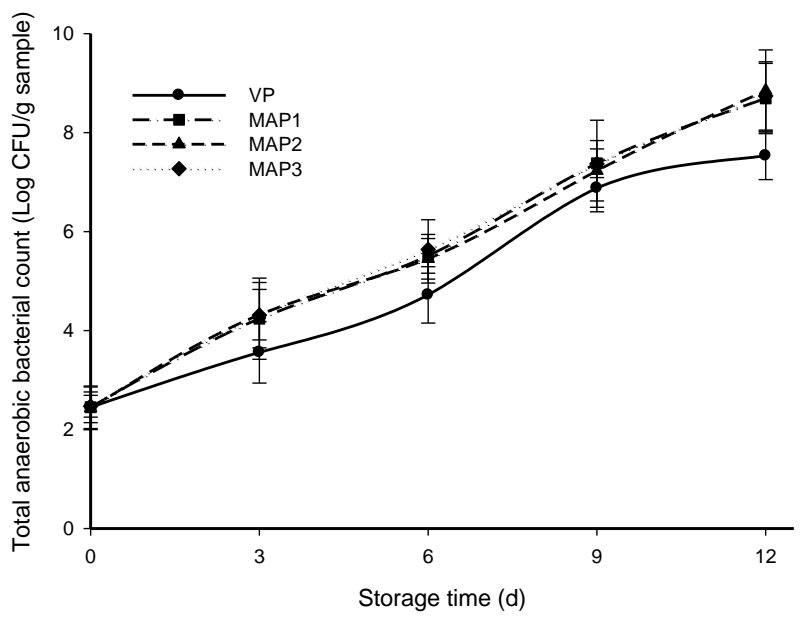

(B)

Figure 3. Effect of gas composition in modified atmosphere packaging on total aerobic (A) and anaerobic bacteria (B) of Longissimus dorsi of Korean Native Black Pig crossbred with Duroc during refrigerated storage. VP, vacuum packaging; MAP, modified atmosphere packaging. MAP1 = 0:20:80/O $: \mathrm{CO}_{2}: \mathrm{N}_{2}, \mathrm{MAP} 2=30: 20: 50 / \mathrm{O}_{2}: \mathrm{CO}_{2}: \mathrm{N}_{2}, \mathrm{MAP} 3=70: 20: 10 / \mathrm{O}_{2}: \mathrm{CO}_{2}: \mathrm{N}_{2}$. 
growth and inhibits growth sensitive anaerobes. Martinez et al. (2006) reported that samples stored without $\mathrm{O}_{2}$ (vacuum or the presence an $\mathrm{O}_{2}$ scavenger) showed the lowest value of aerobic bacterial counts. In addition, meat packaged under vacuum had slower aerobic bacterial growth than that of MAP with $\mathrm{O}_{2}$ (Sheridan et al., 1997). Total anaerobic plate count of all groups increased during storage (Figure 3B). At 3, 6, 9, and $12 \mathrm{~d}$ of storage, total anaerobic plate count of VP was lower $(\mathrm{p}<0.05)$ than that of MAP1, MAP2, and MAP3. There was no significant different total anaerobic plate count among MAP1, MAP2, and MAP3. This might due to the percent of $\mathrm{CO}_{2}$ contained in MAP, where all of three MAP contained $20 \% \mathrm{CO}_{2}$ (McMillin, 2008).

\section{CONCLUSION}

From the present study, it is concluded that MAP with higher oxygen content maintained a higher $\mathrm{a}^{*}$ value of sample during $12 \mathrm{~d}$ storage and higher $\mathrm{L}^{*}$ value at the end of storage. However, the higher rate of lipid oxidation was found in oxygen containing MAP than in non-oxygen MAP and vacuum packaging. Vacuum packaging maintained the lower growth of both aerobic and anaerobic bacteria than MAP throughout the storage. The lower counts of bacteria on VP contributed to the lower protein deterioration of VP than MAP. It is concluded that the MAP containing 30:20:50/ $\mathrm{O}_{2}: \mathrm{CO}_{2}: \mathrm{N}_{2}$ gas composition (MAP2) might be ideal for better meat quality for $\mathrm{KNP} \times \mathrm{D}$ meat.

\section{ACKNOWLEDGMENTS}

This research was supported by Gangwon Sanuri Center for Native Pig Cluster, Republic of Korea.

\section{REFERENCES}

Aida, C., G. Gloria, M. L. José, and M. C. García-Fontán. 2013. Effect of modified atmosphere and vacuum packaging on some quality characteristics and the shelf-life of "morcilla", a typical cooked blood sausage. Meat Sci. 93:220-225.

Borch, E., M. L. K. Muermans, and Y. Blixt. 1996. Bacterial spoilage of meat and cured meat products. Int. J. Food Microbiol. 33:103-120.

Brewer, M. S., L. G. Zhu, B. Bidner, D. J. Meisinger, and F. K. Mckeith. 2001. Measuring pork color: Effects of bloom time, muscle, $\mathrm{pH}$ and relationship to instrumental parameters. Meat Sci. 57:169-176.

Campo, M. M., G. R. Nute, S. I. Hughes, M. Enser, J. D. Wood, and R. I. Richardson. 2006. Flavour perception of oxidation in beef. Meat Sci. 72:303-311.

Cayuela, J. M., M. D. Gil, S. Banon, and M. D. Garrido. 2004. Effect of vacuum and modified atmosphere packaging on the quality of pork loin. Eur. Food Res. Technol. 219:316-320.
Church, N. 1994. Developments in modified-atmosphere packaging and related technologies. Trends Food Sci. Technol. 5:345-352.

Ercolini, D., F. Russo, E. Torrieri, P. Masi, and F. Villani. 2006. Changes in the spoilage-related microbiota of beef during refrigerated storage under different packaging conditions. Appl. Environ. Microbiol. 72:4663-4671.

Esmer, O. K., R. Irkin, N. Degirmencioglu, and A. Degirmencioglu. 2011. The effects of modified atmosphere gas composition on microbiological criteria, color and oxidation values of minced beef meat. Meat Sci. 88:221-226.

Fraser, O. P. and S. Sumar. 1998. Compositional changes and spoilage in fish (part II)-microbiological induced deterioraton. Nutr. Food Sci. 98:325-329.

Garcia-Esteban, M., D. Ansorena, M. Sanchez, and I. Astiasaran. 2003. Optimization of instrumental colour analysis in drycured ham. Meat Sci. 63:287-292.

Grobbel, J. P., M. E. Dikeman, M. C. Hunt, and G. A. Milliken. 2008. Effects of different packaging atmosphere and injectionenhancement on beef tenderness, sensory attributes, desmin degradation, and display color. J. Anim. Sci. 86:2697-2710.

Hwang, I. H., B. Y. Park, S. H. Cho, J. H. Kim, and J. M. Lee. 2004. Identification of muscle proteins related to objective meat quality in Korean native black pig. Asian Australas. J. Anim. Sci. 17:1599-1607.

Jakobsen, M. and G. Bertelsen. 2000. Color stability and lipid oxidation of fresh beef. Development of a response surface model for predicting the effects of temperature, storage time, and modified atmosphere composition. Meat Sci. 54:49-57.

Jakobsen, M. and G. Bertelsen. 2002. The use of $\mathrm{CO}_{2}$ in packaging of fresh red meats and its effect o chemical quality changes in the meat: A review. J. Muscle Foods 13:142-168.

Jayasingh, P., D. P. Cornforth, C. P. Brennand, C. E. Carpenter, and D. R. Whittier. 2002. Sensory evaluation of ground beef stored in high-oxygen modified atmosphere packaging. J. Food Sci. 67:3493-3496.

Jeremiah, L. E., L. L. Gibson, and G. C. Argnosa. 1995. The influence of controlled atmosphere and vacuum packaging upon chilled pork keeping quality. Meat Sci. 40:79-92.

Jeremiah, L. E. 2001. Packaging alternatives to deliver fresh meats using short-or long-term distribution. Food Res. Int. 34:749772.

Jin, S. K., C. W. Kim, Y. M. Song, W. H. Jang, Y. B. Kim, J. S. Yeo, J. W. Kim, and K. H. Kang. 2001. Physicochemical charcteristics of longissimus muscle between the Korean native pig and landlace. Korean J. Food Sci. Anim. Resour. 21:142-148.

John, L., D. Cornforth, C. E. Carpenter, O. Sorheim, B. C. Pettee, and D. K. Whittier. 2005. Color and thiobarbituric acid values of cooked top sirloin steaks packaged in modified atmosphere of $80 \%$ oxygen, or $0.4 \%$ carbon monoxide, or vacuum. Meat Sci. 69:441-449.

Kerry, J. P., M. N. O’Grady, and S. A. Hogan. 2006. Past, current and potential utilisation of active and intelligent packaging systems for meat and muscle-based products: A review. Meat Sci. 74:113-130.

Kim, N. K., J. H. Lim, M. J. Song, O. H. Kim, B. Y. Park, M. J. Kim, I. H. Hwang, and C. S. Lee. 2008. Comparisons of 
longissimus muscle metabolic enzymes and muscle fiber types in Korean and western pig breeds. Meat Sci. 78:455-460.

Kohsaka, K. 1975. Freshness preservation of food and measurement. Food Ind. 18:105-111.

Latorre, M. A., P. Medel, A. Fuentetaja, R. Lázaro, and G. G. Mateos. 2003. Effect of gender, terminal sire line and age at slaughter on performance, carcass characteristics and meat quality of heavy pigs. Anim. Sci. 77:33-45.

Li, X., G. Lindahl, G. Zamaratskaia, and K. Lundström. 2012. Influence of vacuum skin packaging on color stability of beef longissimus lumborum compared with vacuum and highoxygen modified atmosphere packaging. Meat Sci. 92:604-609.

Lund, M. N., R. Lametsh, M. S. Hviid, O. L. Jensen, and L. H. Skibsted. 2007. High oxygen packaging atmosphere influences protein oxidation and tenderness of porcine longissimus dorsi during chill storage. Meat Sci. 77:295-303.

Mancini, R. A. and M. C. Hunt. 2005. Current research in meat color: Review. Meat Sci. 71:100-121.

Martínez, L., D. Djenane, I. Cilla, J. A. Beltrán, and P. Roncalés. 2006. Effect of varying oxygen concentrations on the shelf-life of fresh pork sausages packaged in modified atmosphere. Food Chem. 94:219-225.

McMillin, K. W. 2008. Where is MAP Going? A review and future potential of modified atmosphere packaging for meat. Meat Sci. 80:43-65.

Mendes, R., C. Pestana, and A. Gonçalves. 2008. The effects of soluble gas stabilization on the quality of packed sardine fillets (Sardina pilchardus) stored in air, VP and MAP. Int. J. Food Sci. Technol. 43:2000-2009.

Pexara, E. S., J. Metaxopoulos, and E. H. Drosinos. 2002. Evaluation of shelf life of cured, cooked, sliced turkey fillets and cooked pork sausages - "piroski" - stored under vacuum and modified atmospheres at +4 and $+10^{\circ} \mathrm{C}$. Meat Sci. 62:3343.

Phillips, C. A. 1996. Review: Modified atmosphere packaging and its effects on the microbiological quality and safety of produce. Int. J. Food Sci. Technol. 31:463-479.

Rubio, B., B. Martínez, M. D. García-Cachán, J. Rovira, and I. Jaime. 2008. Effect of the packaging method and the storage time on lipid oxidation and colour stability on dry fermented sausage salchichón manufactured with raw material with a high level of mono and polyunsaturated fatty acids. Meat Sci. 80:1182-1187.

Samelis, J. and K. G. Georgiadou. 2000. The microbial association of Greek taverna sausage stored at 4 and $10^{\circ} \mathrm{C}$ in air, vacuum or $100 \%$ carbon dioxide, and its spoilage potential. J. Appl. Microbiol. 88:58-68.
Santos, E. M., A. M. Diez, G. F. Consuelo, I. Jaime, and J. Rovira. 2005. Microbiological and sensory changes in "Morcilla de Burgos" preserved in air, vacuum and modified atmosphere packaging. Meat Sci. 71:249-255.

Seyfert, M., M. C. Hunt, R. A. Mancini, D. H. Kropf, and S. L. Stroda. 2004. Internal premature browning in cooked steaks from enhanced beef round muscle packaged in high oxygen and ultra-low oxygen modified atmosphere. J. Food Sci. 69:142-146.

Sheridan, J. J., A. M. Doherty, P. Allen, D. A. McDowell, I. S. Blair, and D. Harrington. 1997. The effect of vacuum and modified atmosphere packaging on the shelf-life of lamb primals stored at different temperatures. Meat Sci. 45:107-117.

Sinnhuber, R. O. and T. C. Yu. 1977. The 2-thiobarbituric acid reaction, an objective measure of the oxidative deterioration occurring in fat and oil. J. Jap. Soc. Fish Sci. 26:259-267.

Smiddy, M., N. Papkovskaia, D. B. Papkovskaia, and J. P. Kerry. 2002. Use of oxygen sensors for the nondestructive measurement of the oxygen content in modified atmosphere and vacuum packs of cooked chicken patties; impact of oxygen content on lipid oxidation. Food Res. Int. 35:577-584.

Soldatou, N., A. Nerantzaki, M. G. Kontominas, and I. N. Savvaidis. 2009. Physicochemical and microbiological changes of "Souvlaki" - A Greek delicacy lamb meat product: Evaluation of shelf-life using microbial, color and lipid oxidation parameters. Food Chem. 113:36-42.

SPSS. 2010. Statistical package for social sciences for Windows (version 19.0). SPSS Inc., Chicago, USA.

Suzuki, K., T. Shibata, H. Kadowaki, H. Abe, and T. Toyoshima. 2003. Meat quality comparison of Berkshire, Duroc and crossbred pigs sired by Berkshire and Duroc. Meat Sci. 64:3542.

Tarladgis, B. G., B. M. Watts, and M. T. Younathan. 1960. Distillation method for the determination of malonaldehyde in rancid foods. J. Am. Oil Chem. Soc. 37:44-48.

Viana, E. S., L. A. M. Gomide, and M. C. D. Vanetti. 2005. Effect of modified atmospheres on microbiological, color and sensory properties of refrigerated pork. Meat Sci. 71:696-705.

Yin, M. C., C. Faustman, J. W. Riesen, and S. N. Williams. 1993. $\alpha$-Tocopherol and ascorbate delay oxymyoglobin and phospholipid oxidation in vitro. J. Food Sci. 58:1273-1276.

Zakrys, P. I., S. A. Hogan, M. G. O’Sullivan, P. Allen, and J. P. Kerry. 2008. Effects of oxygen concentration on the sensory evaluation and quality indicators of beef muscle packed under modified atmosphere. Meat Sci. 79:648-655.

Zakrys-Waliwander, P. I., M. G. O’Sullivan, E. E. O’Neill, and J. P. Kerry. 2012. The effects of high oxygen modified atmosphere packaging on protein oxidation of bovine M. longissimus dorsi muscle during chilled storage. Food Chem. 131:527-532. 